\title{
The Model of English Teaching Material for Elementary Schools Teacher Education Based on Contextual Approach
}

\author{
Muji, Nidya Chandra Utami, Rasyid, Yumna, Akhadiah, Sabarti \\ \{nidya chandra@unj.ac.id\} \\ Universitas Negeri Jakarta, Indonesia
}

\begin{abstract}
The aim of this research was to develop a model of English teaching material for elementary school teacher education based on the contextual approach. This was conducted at the elementary school teacher education department of Universitas Negeri Jakarta from July 2016 to December 2017 using the research and development models of Borg and Gall, and Dick and Carey. The data were collected using questionnaires, interviews, and tests (cloze tests and formative tests) instruments and analyzed using both quantitative methods with Paired T-Test and Cohen's Kappa Coefficient and qualitative method with Miles and Huberman's model. The results showed that the developed model had practicality and that it effectively met the needs of the students in the department.
\end{abstract}

Keywords: Teaching materials, English for Specific Purposes, Contextual Approach.

\section{Introduction}

Currently, English is globally used in many fields including technology, business, education, politics, commerce, literature, politics and others. However, the increasing application of the language in many areas requires that English for specific purposes (ESP) should be created and implemented in many universities of Indonesia. This is necessary in order to provide lecturers and students a platform to master the use of the language in their chosen field of study or in accordance with their professions. An example of this can be seen in the "English for elementary school teacher education" course which is available at the elementary school teacher education study program of universities in the country.

Moreover, the existence of the ESP course in elementary school teacher education study program requires that there should be adequate teaching materials suitable to meet the specific competencies needed by the students. This is important because the commercially published English books available contain more of English for general purposes (EGP) rather than English for specific purposes (EGP) required by the users. An ESP teaching material should be designed to meet the needs of its specific users. It is also important to note that they must not be fixated on EGP than for ESP. This is in line with the submission of Chen (2008), Javid (2015) and Bielaswka (2015) that one of the most important aspects of teaching and learning ESP is to have materials that designed and provided for that purpose, where this was observed to aid the achievement of specific professional and academic English competencies [1][2][3]. Furthermore, Hutchinson and Waters in Abudhahir, Mahdun, and Nor (2014) stated that the 
authentic materials and ESP courses are inseparable. Therefore, ESP learners should be provided with authentic materials that reflect reality and the materials to be used should be able to link and relate to the students' background knowledge as well as their language abilities [4].

Munby in Lamri (2016) states that ESP teaching materials must be built on the results of in-depth analysis of the communication needs of students/users and the context of their activities [5]. This is important because the context in which the users will be using the language varies and the language must be developed to suit their varying purposes. Hasibuan (2014) stated that this particular context will also link new experiences/information to be gathered by the students/users of the instructional materials with the knowledge and experiences that they had before. It has also been observed to help in acquiring new knowledge better because of the relation between what they have learnt and the events happening around them [6]. Moreover, Martin et al. in Suryawati and Osman (2018) stated that by relating the students to their contexts, there is improvement in their critical thinking and problem solving skills through the application of various scientific methods[7]. This is in accordance with the principles and foundations of contextual approach[8]. This is the reason why the instructors of ESP learning themselves should ideally design the teaching material rather than using ready-made teaching materials (commercially published books) that are not specifically designed to meet specific English language needs of students[9]. Based on that fact, it is necessary to develop English teaching materials for elementary school teacher education specifically designed to meet the English language needs of students. Therefore, this research was intended to develop a model of English teaching material for elementary school teacher education based on the contextual approach.

\section{Method}

This research employed a mixed method approach because of the quantitative and qualitative nature of data utilized. Research and Development (R\&D) model designed by Borg and Gall as well as Dick and Carey was implemented. The content analysis research method was applied in analyzing the document while purposive sampling was used in determining research subjects. The subject of the research was forty three students of elementary school education program and two experts of English for elementary school education program.

There were four major stages in this study, namely (1) research and information gathering stage which includes preliminary studies and needs analysis, (2) draft development stage which includes planning and developing the initial form of the product, (3) product testing and revision stages which include expert's judgments, one-to-one evaluation, small group evaluation and field test, wherein a revision of the product developed might be applied in each evaluation, and (4) finalization stage.The data were collected using questionnaires, interviews and tests (cloze tests and formative tests) instruments. The collected data were analyzed using both quantitative methods with Paired T-Test and Cohen's Kappa Coefficient and qualitative method with Miles and Huberman's model[10]. The data could be accessed athttps://osf.io/tg6ha/[11] 


\section{Results and Discussion}

Based on the result of preliminary study and deep needs analysis, the teaching material model was developed to describe its content and characteristics dimensions. The content dimension of each module of the developed teaching materaial based on the contextual approach includes the discourses, English skills exercises, and evaluations. The characteristic dimensions of the discourse were (1) containing the taught concept, (2) The selected themes were suitable for elementary school teacher education context, (3) intermediate English proficiency level, (4) intermediate English proficiency level and (4) adjusted to the time allocation. While the characteristic dimensions of the English skills exercises were (1) elaboration of materials, (2) individual or integrated English skills exercises, (3) oriented to the targeted competencies, (4) individual, peer and group work assignments, (5) the use of suitable learning media, (6) the work assignments based on English for elementary school teacher education context and (7) authentic exercises assessments. And the characteristic dimensions of the evaluation developed in this teaching material pertain to its contents in the form of conception questions that measure psychomotor, cognitive and affective knowledge oriented to the fulfillment of targeted competencies. The form was multiple-choice.

Therefore the main characteristic of the model lies in the fact that it is directed towards a specific purpose (ESP), namely English for elementary school teacher education and the specific nature of discourse, English skills exercises, and evaluation based on a contextual approach. The framework of the model is as follows:

Table 1. The Framework of English Teaching Material for Elementary School Teacher Education

\begin{tabular}{cl}
\hline The Modules & \multicolumn{1}{c}{ The Topics } \\
\hline Lesson 1 & Getting to Know The Sentences Constructions \\
\hline Lesson 2 & The Imperative Mood \\
\hline Lesson 3 & $\begin{array}{l}\text { Identifying The Topic, Main Idea and Supporting Details of The } \\
\text { Paragraph }\end{array}$ \\
\hline Lesson 4 & Practical Reading Tips with SQ4R Technique \\
\hline Lesson 5 & Guessing Meaning from Context \\
\hline Lesson 6 & Writing The Essay \\
\hline Lesson 7 & The English Language Skills Learning at Elementary School \\
\hline Lesson 8 & $\begin{array}{l}\text { The Approaches, Methods and Techniques of English Language } \\
\text { Learning for Elementray School }\end{array}$ \\
\hline
\end{tabular}

Moreover, the developed teaching material model was thus tested with a series of tests to determine the practicality and effectiveness of the material. The first evaluation was the expert judgement by using the closed questionnaire developed by Cunningswortin Richards (2017) on seven aspects namely (1) goals and approaches, (2) design and organization, (3) language content, (4) skills, (5) topics, (6) methodology and (7) practical considerations[12]. The questionnaire was given to two English for elementary school education program's experts. The results of the questionnaire were then calculated by the Cohen's Kappa coefficient[13]. The results of the interrater reliability calculation based on the Cohen's Kappa Coefficient calculation using SPSS could be seen in the following tables: 
Table 2. SPSS` Crosstabulation of Reviewer 1 dan Reviewer 2 Output Data

\begin{tabular}{|c|c|c|c|c|}
\hline \multicolumn{5}{|c|}{ Reviewer_1 * Reviewer_2 Crosstabulation } \\
\hline \multicolumn{5}{|c|}{ 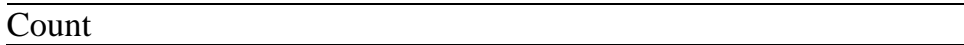 } \\
\hline & & \multicolumn{2}{|c|}{ Reviewer_2 } & \multirow[b]{2}{*}{ Total } \\
\hline & & No & Yes & \\
\hline \multirow[t]{2}{*}{ Reviewer_1 } & No & 1 & 0 & 1 \\
\hline & Yes & 1 & 34 & 35 \\
\hline Total & & 2 & 34 & 36 \\
\hline
\end{tabular}

Tabel 3. SPSS‘ Symmetric Measures Output Data

\begin{tabular}{lcccc}
\hline \multicolumn{5}{c}{ Symmetric Measures } \\
\hline & Value & $\begin{array}{c}\text { Asymp. Std. } \\
\text { Error }^{\mathrm{a}}\end{array}$ & Approx. T $^{\mathrm{b}}$ & $\begin{array}{c}\text { Approx. } \\
\text { Sig. }\end{array}$ \\
\hline Measure of Agreement & Kappa & .654 & .320 & 4.182 \\
\hline N of Valid Cases & \multicolumn{3}{c}{.000} \\
\hline a. Not assuming the null hypothesis. & 36 & & & \\
\hline b. Using the asymptotic standard error assuming the null hypothesis. \\
\hline
\end{tabular}

The Cooefisein Cohen's Kappa value from the SPSS output was 0.654. The value then when compared with the Altman's strength of agreement criterias(Altman in Azzainuri, 2013)meantthat there was a strong agreement between reviewers 1 and Reviewer 2 on the carried out assessment[13]. While the results of statistical calculations with SPPS also found that the significance value could be seen in the column Approx. Sig., In the table above, a significance value of 0,000 . Because the significance value was smaller than the significance level used $5 \%(0,000<0,05)$, it can be concluded that the initial hypothesis could be rejected. Thus it was concluded that there was a significant agreement between Reviewer 1 and Reviewer 2 at a significance level of $5 \%$.

The second evaluation was one-to-one evaluations in the form of readability tests by using the cloze tests which was developed by Taylor in Sitepu (2010). The cloze tests were given to three research respondents who were students of elementary school teacher education program. Thus, the tests results showed that the average level of readability of module 1 of the developed teaching material was $88,89 \%$, module 6 was $90 \%$ and module 8 was $89,92 \%$. The average score of material's readabilityin one to one evaluation which ranged from $88,89 \%$ to $90 \%$ meant that the developed teaching material's readabilty was fulfilling the criteria of good readability of $>50 \%[14]$.

The third evaluation was small group evaluation in the form of readability tests by using the cloze tests which was developed by Taylor. The cloze tests were given to 10 research respondents (not including the three respondents who took the one to one evaluation) who were students of elementary school teacher education program.Thus, the tests results showed that the average level of readability of module 2 of the developed teaching material was $81,54 \%$, module 4 was $87,25 \%$ and module 7 was $86,75 \%$. The average score of material's readabilityin small group evaluation which ranged from $81,54 \%$ to $87,25 \%$ also meant that the developed teaching material's readabilty was fulfilling the criteria of good readability of $>50 \%[14]$.

Finally the fourth evaluation was the field test using the formative tests in the form of pre-test and post-test. Before the tests were carried out, a limited scale trial was conducted by using the developed teaching material in the "English for elementary school teacher 
education" course in the elementary school teacher education study program eight times in one class with forty-three students. Learning is preceded by a pre-test and ends with a posttest. Thus, the tests were given to 30 research respondents (not including the three respondents who took the one to one evaluation and ten respondents who took the small group evaluation) who were students of elementary school teacher education program.From the carried tests, it was found that the average score of the pre-test was 68,17 and the average score of the posttest was 75,75. Data from the pre-test and post-test results were then tested with Paired T-Test with SPSS. The results from the Sample Correlation Test Paired with SPSS can be seen in the tables below:

Table 4. SPSS Paired Sample Tests Output Data

\begin{tabular}{|c|c|c|c|c|c|c|c|c|c|}
\hline \multicolumn{10}{|c|}{ Paired Samples Test } \\
\hline & & \multicolumn{5}{|c|}{ Paired Differences } & \multirow[b]{3}{*}{$t$} & \multirow[b]{3}{*}{$d f$} & \multirow{3}{*}{$\begin{array}{l}\text { Sig. (2- } \\
\text { talled) }\end{array}$} \\
\hline & & \multirow[b]{2}{*}{ Mean } & \multirow{2}{*}{$\begin{array}{c}\text { Std. } \\
\text { Deviation }\end{array}$} & \multirow{2}{*}{$\begin{array}{c}\text { Std. Error } \\
\text { Mean }\end{array}$} & \multicolumn{2}{|c|}{ of the Difference } & & & \\
\hline & & & & & Lower & Upper & & & \\
\hline $\operatorname{Pair} 1$ & $\begin{array}{l}\text { Pretest - } \\
\text { Postest }\end{array}$ & $-3,033$ & 2,356 & .430 & $-3,913$ & $-2,154$ & $-7,052$ & 29 &, 000 \\
\hline
\end{tabular}

From the SPPS output table above, we get a significance value (Sig. 2 tailed) of 0,000 which meant significant at the 0.01 level. Sig. (2-tailed): Probability value / $\mathrm{p}$ value of T Paired test, the result is 0,000 . This meant that there was a difference between before and after treatment, because the $\mathrm{p}$ value was $<0.05$ (95\% confidence) or in other words there were significant differences between the pre-test group and the post-test group. Mean = -3,033. Mean negative meant that there was a tendency to increase in value after treatment. The average increase was 3,033. From the results of the test above, we could assume that English teaching materials for elementary school teacher education based on the contextual approach that has been developed can contribute to the improvement of English language competence of elementary school teacher education students. Finally based on the results of the series of carried evaluations, it can be concluded that the developed English teaching material met the practicality and effectiveness factors for an ESP teaching material.

\section{Conclusion}

The English teaching material for elementary school teacher education based on the contextual approach model that was developed in this study is a student book which contains "input" in the form of discourse, training for deepening concepts or developing English skills and competency tests containing questions as a measure of learning outcomes. The content of the materials has to do with discourse relating to English for elementary school teacher education. This was followed by training to improve insight into English needed by users as well as relevant competency tests. In general, the materials developed are interesting and easy to be used by users. The resulting model is also effective in forming and increasing the English language competencies for the users of the materials. However, there are some elements related to this teaching material that were not researched, therefore, further research is recommended to cover these elements through widespread sample handling and experimental methodology in more complete product testing. 


\section{References}

[1] Y. Chen, "Material Production for an EST Course: Coursebook Design for the English Training Programme for Architects and Civil Engineers," Scr. Manent- J. Slov. Assoc. LSP Teach., vol. 3, no. 2, pp. 82-104, 2008.

[2] C. Z. Javid, "English for Specific Purposes: Role of Learners, Teachers and Teaching Methodologies," Eur. Sci. J., vol. 11, no. 20, pp. 17-34, 2015.

[3] E. D. Lesiak-Bielawska, "Key Aspects of ESP Materials Selection and Design," English Specif. Purp. World, no. 46, p. 12, 2015.

[4] A. M. Abudhahir, R. A. S., Mahdun, M., \& Nor, "Needs Analysis and Material Development in English for Specific," E-proceedings Conf. Manag. Muamalah, no. May, pp. 978-983, 2014.

[5] Lamri, Chams Eddine., "An Introduction to English for Specific Purposes (ESP)," Tlemcen, 2016.

[6] Hasibuan., H., M, "Model Pembelajaran CTL,” Logaritma, vol. II, no. 01, pp. 1-12, 2014.

[7] Evi Suryawati and Kamisah Osman, "Contextual Learning: Innovative Approach towards the Development of Students' Scientific Attitude and Natural Science Performance," EURASIA Journal of Mathematics, Science and Technology Education, vol. 14, no. 1. pp. 61-76, 2018.

[8] Johnson, Elaine. B., CTL: Contextual Teaching and Learning, 1st ed. Bandung: Mizan Learning Center, 2014.

[9] B. Klimova, "Developing ESP Study Materials for Students at a Non-philological Faculty,” Procedia - Soc. Behav. Sci., vol. 197, no. February, pp. 104-107, 2015.

[10] Emzir, Metodologi Penelitian Pendidikan: Kuantitatif dan Kualitatif, Revised. Jakarta: P.T Raja Grafindo Perkasa, 2010.

[11] Nidya, "https://osf.io/tg6ha/." 2019.

[12] Richards, Jack., C., Curriculum Development in Language Teaching, 2nd ed. Cambridge: Cambridge University Press, 2017.

[13] Azzainuri, "Koefisien Cohen's Kappa," 2013. [Online]. Available: https://parameterd.wordpress.com/2013/.../koefisien-cohens-kappa/. [Accessed: 07Oct-2016].

[14] Sitepu, B., P., “KETERBACAAN," 2010. . 